International Journal of Instruction e-ISSN: 1308-1470 • www.e-iji.net

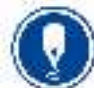

July $2021 \bullet$ Vol.14, No.3

p-ISSN: 1694-609X

pp. 207-222

Article submission code 20200617052919

Received: 17/06/2020

Revision: 07/12/2020
Accepted: 30/12/2020

OnlineFirst: 24/04/2021

\title{
Study to Assess Attitudes towards Statistics of Business School Students: An Application of the SATS-36 in India
}

\section{Aarti Mehta Sharma}

Assoc. Prof., Department of Professional Studies, Christ University, Bengaluru, Karnataka 560029, India, aartimehta.sharma@christuniversity.in

\section{Anshu Srivastav}

An independent researcher based in Mumbai, India, anshu.srivastav@gmail.com

Student's attitudes towards Statistics are pivotal to their learning process as positive attitudes lead to highly satisfactory course achievement and lead to positive outcomes outside class as well. In this paper we are exploring the perception of students of management apropos Statistics, familiarity with which is imperative in today's world of Analytics. The quantitative approach was used to compare attitudes of the students using the two versions of the "SATS-36" instrument validated and copyrighted by Candace Schau. A Google form was used to collect responses and was sent to all the students who were enrolled in the Business Statistics course. 172 students responded for the pre-test study while 71 students responded for the post-test study. Data was analysed to see if gender, specialisation choices and previous math experiences accounted for differences in perceptions towards Statistics. It was found that students' overall perception of statistics is positive and surprisingly they were more positive towards the beginning of the semester. These results are important as they can lead towards understanding of business student's attitudes towards statistics and a way to refine the teaching learning process so that students are in a strong position to exploit the supply demand gap in the Analytics domain and deliver value to organisations.

Keywords: attitude, statistics education, business education, curriculum, pre-test, posttest, SATS-36, factor analysis

\section{INTRODUCTION}

"Statistics ...the most important science in the whole world: for upon it depends the practical application of every other science and of every art; the one science essential to all political and social administration, all education, all organisation based upon experience, for it only gives the results of our experience. -Florence Nightingale."

Data Science is one of the fastest growing fields in industry and now Academia as it has benefited corporates by driving productivity, encouraging faster and better decision making, and thus increasing net revenues. The widespread use of Enterprise Resource

Citation: Sharma, A. M., \& Srivastav, A. (2021). Study to Assess Attitudes towards Statistics of Business School Students: An Application of the SATS-36 in India. International Journal of Instruction, 14(3), 207-222. https://doi.org/10.29333/iji.2021.14312a 
Planning systems, the internet and various mobile apps by industry and individuals has given rise to a vast amount of data also known as "Big Data". This stream of information has peculiarities which has to be treated by statisticians before it can be mined (François et al., 2020). Students should be able to work with big data and become responsible citizens of society (Howley et al., 2017). Most large organisations are mining the data to derive value to users and corporates. In today's time of the Corona pandemic it is also being used to track and control the epidemic(Katyal, 2020; Vaidya, 2020). A recent report by the Bureau of Labor Statistics, USA (https://www.bls.gov/emp/images/growing_occupations.png) says that the job of a data scientist or a statistician is among the ten jobs that are projected to grow the fastest in the United States of America. Another report (https://www.bls.gov/news.release/pdf/ecopro.pdf) says that the overall employment of statisticians will grow by $30.7 \%$ percent in the current decade of 2018 to 2028. This rate of growth is the fastest growth for any occupation in the business sphere. Businesses will need statisticians to analyze the ever increasing digital and electronic data and derive value from it.

Closer home, in India, a 2018 report (NASSCOM, 2018) by the "National Association of Software and Service Companies (NASSCOM"), says that there is a huge demand for big data analysts in India. The report projects that the talent demand in 2021 will be $2,30,000$ jobs and the supply will be 90,000 jobs with a gap of 140,000 jobs. Seventysix percent of these jobs are related to data science. These current job openings are being filled by engineers, mathematicians, statisticians and business school graduates. While mathematicians and statisticians have a solid grounding in statistics, it is essential for engineers and business school students to be trained in the art and science of the subject. At times, even if students are familiar with the subject of statistics they do not like it as they believe it to be a difficult course which is related to mathematics and computers. Such beliefs are dangerous as they dissuade learning of statistics and stop students from applying what they have learned. In such a case if they do not enjoy the course it can threaten their chances of completing their degree (Onwuegbuzie \& Wilson, 2003).

Statistics is used in all areas of business be it Market Research, Financial Modelling, Quality Control, Product Planning, Forecasting, etc. The knowledge of Statistics helps managers take informed decisions thereby guiding businesses to do better in an uncertain future. Over the years' students of management have found statistics to be more difficult than other subjects. This may be due to a poor mathematical background or a general disinterest in the subject or a feeling that it will be of no help in their careers after completing an MBA. These attitudes are very important as they are a result of their experiences formed over time while participating in the course at school or undergraduate level; and if students' attitudes can be changed then there might develop an affinity for the subject.

An attempt was made to gauge learners' attitudes towards Statistics; primary data was collected through an online instrument. The respondents were MBA students of Symbiosis Institute of Business Management (SIBM), Bangalore and it was mandatory 
for them to take the Business Statistics course in the First Semester (2018-19). The participants would then be doing specialization in different business domains like Marketing, Finance, Operations and Human Resource Management in the $2^{\text {nd }}$ year. They were requested to fill-up the "pre-test" survey form before the commencement of the course to gauge their expectations about the course and the "post-test" survey form of the SATS-36 instrument to understand their attitudes towards the course after completing the course. Data were collected in June 2018 from 172 students for the pretest study which was conducted before the course began, while 71 students responded for the post-test study in October 2018, which was conducted after the semester was over. The quantitative approach was used to compare attitudes of the students through the two version of the "SATS-36" instrument validated and copyrighted by Candace Schau. This much used and respected instrument consists of 36 items that evaluate six attitude aspects: "Affect", "Cognitive Competence", "Value", "Difficulty", "Interest" and "Effort". Responses of those taking the course were collected on a 7-point Likert response scale $(1=$ "Strongly Disagree", 4 = "Neither Disagree nor Agree", 7 = "Strongly Agree"). The statements for each of the six constructs are given in table 1. The techniques of Factor analysis, Students t-test and univariate analysis of variance (ANOVA) were applied to analyse the responses, and compare responses before and after the semester.

The objective was to understand the attitude of business students towards statistics on the components mentioned above. Secondary objectives were to see if there was a difference before and after taking the course, if there were differences in perception due to gender, future specialisation choices and earlier experiences with math. In these times when mathematical models are being examined to stop the spread of epidemics, it is even more important to address issues of statistical anxiety and to connect students with statistics.

\section{Literature Review}

Research studies conducted earlier have indicated that student attitudes and success are connected (DeVaney, 2009; Griffith et al., 2012; Vanhoof et al., 2011). It is important to know about students' attitudes towards Statistics as it impacts not only the way they learn but their learning outcomes as well. Hence, it is important to select the correct tool to assess these attitudes. There have been a number of tools used to assess students' attitudes towards Statistics. The "Statistics Attitudes Survey"(Roberts \& Bilderback, 1980) with 33 items correlated cognition with outcomes, the "Attitudes towards Statistics" (Wise, 1985) measured "Attitudes towards Course" itself as well as "Attitudes towards field". The "Survey of Attitudes Toward Statistics" (Dauphinee et al., 1997; Schau, 2003) is the most recent and the most comprehensive one. It started with 28 items and four subscales and was later expanded to include two more subscales taking the number of items to 36 and hence the name SATS-36. Through this scale, students attitudes towards Statistics are measured through the prisms of the 6 subscales namely, "Affect", "Cognitive Competence", "Value", "Difficulty", "Interest" and "Effort", where the latter two were added later. 
As statistics educators if we know the perception of the classes we take then we can do a better job in serving the teaching community and serving society as a whole by providing solutions to society and businesses. It has become imperative for all stakeholders to understand the nuances of Analytics - where analytics consists of statistics, the technology that goes with it and most important the ability to solve business problems.

A number of studies have shown that there are differences in perception of statistics between the genders. While some researchers say that there is no difference (Aslemand, 2018;Hassad, 2018; Alizamar et.al, 2019) there are others (Coetzee \& Merwe, 2010; Mónica et al., 2016; Martin et al., 2017; Sharma, 2018; Paul \& Cunnington, 2017; Hommik \& Luik, 2017) that find males were more inclined toward statistics than females. Female students report being more anxious than male students over scoring in Statistics(Fullerton \& Umphrey, 2001a). Female students were also more likely to ask for help (Fullerton \& Umphrey, 2001b; Mandap, 2016). (Sharma, 2018) says that perceptions to statistics education differ to a certain extent on gender. Some studies have found older students to be better inclined than younger ones towards Statistics (Coetzee \& Merwe, 2010). Perceptions towards statistics are also found to be related to previous experiences with mathematics at any level. Students who did well in earlier mathematics courses believed that they would do well in Statistics courses. Studies have found that that a part of the achievements in statistics could be due to previous success in mathematics (Bond et al., 2012; Paechter et al., 2017,Roberts \& Bilderback, 1980). While it is envisaged that students will be more favourable towards the subject after studying it and completing the course, the contrary has often been true (Bond et al., 2012; Melad, 2016).

\section{METHOD}

The objective(s) of this study are:

1. To examine the attitude of business students towards statistics.

2. To examine the influence of gender, specialisation choices or previous mathematics experiences on the attitude of business students towards the statistics course.

3. To examine if there is a difference in student's attitude before and after taking the course.

4. To adapt the SATS-36 model to a sample of Indian business school students

While several studies have been conducted in measuring and monitoring attitudes of learners towards statistics we have utilized the "Survey of Attitudes Toward Statistics (SATS-36)" scale which was developed and validated by Schau (Dauphinee et al., 1997). This scale has regularly demonstrated acceptably on validity and reliability (Zhao et al., 2013), has "solid theoretical underpinnings...based on a number of popular theories including expectancy value, attribution, social cognition, and goal theories" (Griffin, et al. 2012) and enables researchers to understand why some students value statistics more than other students and what leads them to varying choices in academics and outside (Chiesi \& Primi, 2010; Hood, Creed \& Neumann, 2012; Sorge \& Schau, 
2002). The constructs in Student's Attitudes Toward Statistics model focus on the differing and unchanging nature of students' attitudes and course outcomes" (Ramirez et al., 2012). It was first conceptualized and then validated as the SATS-28 (Dauphinee et al., 1997) which considered the four perspectives of: "Affect", "Cognitive Competence", "Value", and "Difficulty" (italics in original article). "SATS-28" was later updated to "SATS-36" (Schau, 2003) with the two more attitudes components of "Interest", and "Effort" (italics in original article). The two versions of SATS-36; one to administer before and one after a statistics course are the same, just the tense is different.

\section{Structure of SATS-36}

The "SATS-36" comprises of 36 items which examine perception of students about Statistics through the six attitude components mentioned above. Responses to each of these items are recorded on a 7-point Likert scale ( $1=$ "Strongly Disagree", $4=$ "Neither Disagree nor Agree", 7 = "Strongly Agree"). Scores for some negatively worded items like "I will feel insecure when I have to do statistics problems" are reversed and then combined into component scores. This means that bigger scores for every component (leaving "Difficulty") reveal positive attitudes. The explanation for each component is given in Table 1.

Table 1

SATS-36

\begin{tabular}{llll}
\hline Component & Meaning & Example Item & $\begin{array}{l}\text { Number } \\
\text { of Items }\end{array}$ \\
\hline "Affect" & Students perception of the subject & "I will like Statistics." & 6 \\
\hline $\begin{array}{l}\text { "Cognitive } \\
\text { Competence" }\end{array}$ & $\begin{array}{l}\text { Students confidence on their } \\
\text { ability to deal with the subject }\end{array}$ & "I can Learn Statistics." & 6 \\
\hline "Value" & $\begin{array}{l}\text { Students' perception about how } \\
\text { relevant the subject is }\end{array}$ & $\begin{array}{l}\text { "Statistical Skills will make } \\
\text { me more employable." }\end{array}$ & 9 \\
\hline "Difficulty" & $\begin{array}{l}\text { Learners perception about the } \\
\text { complexity of the subject }\end{array}$ & $\begin{array}{l}\text { "Statistics is a subject quickly } \\
\text { learned by most people." }\end{array}$ & 7 \\
\hline "Interest" & $\begin{array}{l}\text { Independent interest in the } \\
\text { subject }\end{array}$ & $\begin{array}{l}\text { "I am interested in being able } \\
\text { to use Statistics." }\end{array}$ & 4 \\
\hline "Effort" & $\begin{array}{l}\text { Amount of labour students expect } \\
\text { will be needed for this subject }\end{array}$ & $\begin{array}{l}\text { "I plan to work hard in my } \\
\text { Statistics course." }\end{array}$ & 4 \\
\hline
\end{tabular}

The details of the same and scoring method are available at (http://www.evaluationandstatistics.com/index.html). While a lot of studies have been done on this scale there are some studies that validate this scale with six factors(Emmioglu Sarikaya et al., 2018; Persson et al., 2019; Vanhoof et al., 2011) and others studies that support seven scales(Khavenson et al., 2012) or even four scales (Hommik \& Luik, 2017). Our study attempts to check efficacy of the "SATS-36" scale to post graduate business students in India. The questionnaire was applied in English.

The respondents in the study were enrolled in the Business Statistics course for the First Semester (2018-19), limited to the MBA students of SIBM, Bangalore. The MBA course in India is a two year full time programme as defined by the "University Grants Commission (UGC)", which is the nodal agency for higher education in India 
("https://www.ugc.ac.in/oldpdf/modelcurriculum/mba.pdf"). It typically consists of 4 semesters, with an 8-12 weeks' summer project after semester 2. In the second year students select subjects of their choice. The participants would be selecting specialization subjects in different business domains like Marketing, Finance, Operations and Human Resource Management in the $2^{\text {nd }}$ year. Students in this research study answered to both the forms of the "SATS-36" to compare the attitudes towards the course. The number of participants for the pre-test was 172 (74 female and 98 male) while for the post-test was 71 (27 female and 44 male). The questionnaire was circulated to all the students who took the course for both the pre test and post test. Only 71 decided to fill the post course questionnaire.

\section{FINDINGS AND DISCUSSION}

\section{Attitude Towards the Course of Statistics}

Attitudes towards statistics were measured by student's responses through questions related to statistics topic on the six components in the instrument. Microsoft Excel and R programming language were used for this study.

Table 2 given below gives us the overall score for each item, the score gender wise and the $\mathrm{p}$ value for the test to check for differences in responses between the two genders. These responses were collected before the course started. The highest score of 6.75 is for the item "I plan to work hard in my statistics course", followed by "I plan to complete all my assignments (6.740)" and "Statistical skills will make me more employable (6.610)". This shows that students are keen to work hard in the subject as they know that the knowledge of statistics will get them better jobs. This understanding is also borne out by the negative worded statements like "Statistics is not useful to the typical professional" with a low score of 1.640 and "Statistics is worthless" which has got a score of 1.349. There is also an anticipation of the subject being difficult as shown by the responses "Statistics is a complicated subject" with a score of 3.901 and "I will find it difficult to understand statistical concepts" with a score of 3.081. The construction of items which do not have a significant $\mathrm{p}$ value have been changed, but the meaning remains the same. 
Table 2

Responses to the statements before the semester started

\begin{tabular}{|c|c|c|c|c|}
\hline Variables & $\begin{array}{l}\text { Overal } \\
1 \text { Mean }\end{array}$ & $\begin{array}{l}\text { Mean } \\
\text { Female }\end{array}$ & $\begin{array}{l}\text { Mean } \\
\text { Male }\end{array}$ & $\mathrm{p}$ value \\
\hline I am planning to finish all my assignments & 6.740 & 6.767 & 6.727 & 0.616 \\
\hline I will work hard in this course & 6.750 & 6.767 & 6.747 & 0.800 \\
\hline I will enjoy this course & 5.690 & 5.671 & 5.697 & 0.888 \\
\hline I will feel insecure when I have to do statistics problems & 3.314 & 3.767 & 2.980 & $0.00356 *$ \\
\hline I will have problems in this subject & 3.041 & 3.274 & 2.869 & 0.126 \\
\hline Formulas are easy to understand in this subject & 4.453 & 4.452 & 4.455 & 0.991 \\
\hline Statistics has no worth & 1.349 & 1.384 & 1.323 & 0.705 \\
\hline This subject is complicated. & 3.901 & 4.096 & 3.758 & 0.174 \\
\hline My professional training should have Statistics & 6.395 & 6.370 & 6.414 & 0.754 \\
\hline $\begin{array}{l}\text { Skills in this subject will give me value in the job } \\
\text { market. }\end{array}$ & 6.610 & 6.630 & 6.596 & 0.760 \\
\hline I will have no clue of what is happening in this course & 2.047 & 2.096 & 2.010 & 0.696 \\
\hline $\begin{array}{l}\text { I want to communicate information in the form of } \\
\text { statistics }\end{array}$ & 6.030 & 6.164 & 5.939 & 0.187 \\
\hline The typical professional does not find Statistics useful & 1.640 & 1.699 & 1.596 & 0.537 \\
\hline I will study hard for every test in statistics & 6.480 & 6.397 & 6.545 & 0.332 \\
\hline I will get frustrated going over statistics tests in class & 2.587 & 2.836 & 2.404 & $0.08219 * * *$ \\
\hline $\begin{array}{l}\text { Outside my job I will not need to apply statistical } \\
\text { thinking. }\end{array}$ & 1.849 & 1.918 & 1.798 & 0.579 \\
\hline I apply statistics in my day to day life & 5.170 & 5.356 & 5.040 & 0.169 \\
\hline I will be under stress during statistics class. & 3.000 & 3.370 & 2.727 & $0.01248 * *$ \\
\hline I will enjoy taking statistics courses. & 5.510 & 5.342 & 5.626 & 0.185 \\
\hline The use of Statistics interests me & 6.010 & 5.932 & 6.071 & 0.433 \\
\hline $\begin{array}{l}\text { Statistics conclusions are rarely presented in everyday } \\
\text { life }\end{array}$ & 2.360 & 2.438 & 2.303 & 0.592 \\
\hline Statistics can be quickly learned. & 3.750 & 3.603 & 3.859 & 0.250 \\
\hline Understanding statistical information interests me. & 6.160 & 6.137 & 6.172 & 0.836 \\
\hline Discipline is required while learning statistics & 5.959 & 6.055 & 5.889 & 0.337 \\
\hline $\begin{array}{l}\text { There will be no application for statistics in my } \\
\text { profession. }\end{array}$ & 1.674 & 1.781 & 1.596 & 0.315 \\
\hline I expect I will have math errors in statistics. & 3.209 & 3.178 & 3.232 & 0.833 \\
\hline I will every statistics class session. & 6.720 & 6.753 & 6.697 & 0.471 \\
\hline I am scared by statistics. & 3.308 & 3.863 & 2.899 & $0.0007937 *$ \\
\hline Learning statistics interests me. & 6.390 & 6.370 & 6.404 & 0.821 \\
\hline Statistics involves massive computations & 5.192 & 5.452 & 5.000 & $0.02855 * *$ \\
\hline I can learn statistics & 6.340 & 6.247 & 6.404 & 0.277 \\
\hline I will understand statistics equations & 5.940 & 5.822 & 6.020 & 0.234 \\
\hline There is no relevance of Statistics in my life & 1.698 & 1.808 & 1.616 & 0.302 \\
\hline This subject is very technical & 4.669 & 4.877 & 4.515 & 0.105 \\
\hline I will find it difficult to understand statistical concepts & 3.081 & 3.329 & 2.899 & $0.06297 * * *$ \\
\hline $\begin{array}{l}\text { To learn statistics, most people have to start thinking } \\
\text { differently. }\end{array}$ & 4.448 & 4.616 & 4.323 & 0.194 \\
\hline
\end{tabular}




\section{Influence Of Gender, Specialisation Choices Or Previous Mathematics Experiences Gender Differences}

Table 2 shows that out of the 36 statements in the instrument, responses between male and female students differ in only 6 statements. Interestingly out of these six statements, four of them are from the affect component, one is from the difficulty component and one is from cognitive competence. The items "I will feel insecure when I have to do statistics problems", "I will get frustrated going over statistics tests in class", "I will be under stress during statistics class" and "I am scared by statistics" correspond to the affect component. "Statistics involves massive computations" corresponds to the component of difficulty. The item "I will find it difficult to understand statistical concepts" corresponds to the component of cognitive competence. The apprehension of female respondents is greater as compared to their counterparts on these items. Further analysis was conducted by combining items into the six components as defined by Schau and the results are shown in Table 3 . These results corroborate the earlier findings that the significant differences between the genders are for the components of "Affect" and "Difficulty". A positive finding from the scores in table 3 is that students find the subject to be of high value and interest and are prepared to put in effort to do well, as borne out by the high scores for "Value", "Interest" and "Effort". These high scores are for both the genders.

Table 3

Results from $t$ test for gender differences for pre-test responses

\begin{tabular}{llll}
\hline Results from t test for gender differences & & & \\
\hline Attitude Components & Mean Female & Mean Male & p value \\
\hline Affect & 4.8630 & 5.3900 & $0.0046^{* *}$ \\
\hline Cognitive Competence & 5.3653 & 5.5690 & 0.1837 \\
\hline Value & 6.1476 & 6.2020 & 0.6578 \\
\hline Difficulty & 3.2798 & 3.5469 & $0.0373^{*}$ \\
\hline Interest & 6.1507 & 6.1465 & 0.9748 \\
\hline Effort & 6.6712 & 6.6793 & 0.9048 \\
\hline
\end{tabular}

*Significant at 5\%

** Significant at $1 \%$

\section{Specialisation Differences}

In this section, we examine if there are differences in responses to the survey according to specialisation choices which students would opt for in the second year. Students can specialise in either one of the four streams: Human Resources, Operations, Finance or Marketing. The analysis was conducted by running one way ANOVAs with the six attributes individually. The results of the ANOVA are given in Table 4 where it is clear that statistically significant differences are present in responses to attributes of "Affect", "Cognitive Competence" and "Difficulty". Results show that those who intend to pursue Human resources are the most apprehensive about taking the course (Affect mean is lowest at 4.495). Students who plan on taking Finance and Operations are most confident of acing the subject as their scores on Cognitive competence are higher than the other two at 5.84 and 5.7. While the scores on expected difficulty level are between 
3 and 4 for all the categories of students, those who were planning to take Operations (3.82) and Finance (3.58) expected the course to be marginally less difficult.

Table 4

Results from ANOVA and post hoc for specialisation

\begin{tabular}{|c|c|c|c|c|c|c|}
\hline $\begin{array}{l}\text { Attitude } \\
\text { Components }\end{array}$ & Marketing & $\begin{array}{l}\text { Human } \\
\text { Resources }\end{array}$ & Operations & Finance & $\mathrm{p}$ value & Tukey HSD test \\
\hline Affect & 5.063 & 4.495 & 5.392 & 5.552 & 0.000 & $\begin{array}{l}\text { Difference exists between } \mathrm{HR} \text { and } \\
\text { Finance }(\mathrm{p}=0.00) ; \mathrm{HR} \text { and } \\
\text { Operations }(\mathrm{p}=0.03)\end{array}$ \\
\hline $\begin{array}{l}\text { Cognitive } \\
\text { Competence }\end{array}$ & 5.298942 & 5.032258 & 5.7 & 5.847701 & 0 & $\begin{array}{l}\text { Differences between HR and } \\
\text { Finance }(p=0.00), \text { Marketing and } \\
\text { Finance }(p=0.007)\end{array}$ \\
\hline Value & 6.091711 & 6.032258 & 6.288889 & 6.314176 & 0.225 & No Differences \\
\hline Difficulty & 3.3583 & 3.046083 & 3.82857 & 3.586207 & 0.00286 & $\begin{array}{l}\text { Difference between HR and } \\
\text { Finance }(\mathrm{p}=0.015), \mathrm{HR} \text { and } \\
\text { Operations }(\mathrm{p}=0.005)\end{array}$ \\
\hline Interest & 6.2024 & 5.967742 & 6.1875 & 6.172414 & 0.608 & No Differences \\
\hline Effort & 6.6746 & 6.612903 & 6.7125 & 6.698276 & 0.809 & No Differences \\
\hline
\end{tabular}

\section{Difference In Attitudes Due To Previous Math Experience}

Responses were then analysed with respect to previous math experience. The question asked of all respondents was "How well did you do in mathematics courses you have taken in the past?". The responses were on a scale of 1-7 where 1 corresponded to "Very Poorly" and 7 corresponded to "Very Well". These responses were then categorised into three classes where responses of 5,6 and 7 were categorised as positive, responses of 1,2 and 3 were categorised as negative and a response of four was considered to be neutral. The results are given in Table 5. Significant differences were realised in the attributes of "Affect" besides "Cognitive Competence". These differences are between those who perceive their previous math experiences to be positive and negative. Those students who have positive experiences with math earlier, have scored higher on the two attributes mentioned earlier. The analysis displayed in tables 3,4 and 5 clearly bring out the differences present in responses to the attributes of Affect, Cognitive Competence and Difficulty.

Table 5

Results from ANOVA and post hoc for Math Performance

\begin{tabular}{llllll}
\hline $\begin{array}{l}\text { Attitude } \\
\text { Components }\end{array}$ & Positive & Neutral & Negative & $\mathrm{p}$ value & \begin{tabular}{l} 
Tukey HSD test \\
\hline Affect
\end{tabular} \\
\hline & 5.392 & 4.808333 & 4.37037 & 0 & $\begin{array}{l}\text { There is significant difference between } \\
\text { categories of positive and negative }(\mathrm{p}=0.00)\end{array}$ \\
$\begin{array}{l}\text { Cognitive } \\
\text { Competence }\end{array}$ & 5.696 & 5.083333 & & & $\begin{array}{l}\text { There is significant difference between } \\
\text { positive and negative }(\mathrm{p}=0.00) \text { and positive } \\
\text { and neutral ( } \mathrm{p}=0.015)\end{array}$ \\
\hline Value & 6.249778 & 6.127778 & 5.888889 & 0.071 & No Differences \\
\hline Difficulty & 3.497143 & 3.435714 & 3.137566 & 0.126 & No Differences \\
\hline Interest & 6.224 & 5.9375 & 5.953704 & 0.145 & No Differences \\
\hline Effort & 6.712 & 6.6 & 6.564815 & 0.188 & No Differences \\
\hline
\end{tabular}




\section{Differences In Pre-Test And Post-Test Responses}

Table 6 shows the sub scores, conducted on a 7-point Likert scale for the components recorded before and after the course was conducted. Five components score above 4 on average, on the survey conducted before the course commencement, whereas "Difficulty" has a lower score. This component can be thought of as perceived easiness and thus lower values should be interpreted as "statistics is a difficult subject" whereas higher values mean "statistics is easy". Responses to all six attributes were analysed before and after the semester. It is interesting to note that except for the attribute of "Difficulty" the scores for the post-test responses are lower than the pre test scores. This shows that the students found the course to be marginally more difficult than they expected. It also shows that they liked it marginally less than expected, they found it harder than expected to learn, they found it lesser in value than expected. There was a drop in almost all of the subscales with "Effort" having the largest drop of 0.62 units. These are indications that the teaching learning process should be re-examined. A t test was run to check for significant differences among the two sets of scores. The results yielded differences in the attributes of "Value", "Interest" and "Effort". Students did not find the subject as relevant as they had expected it to be as score before the semester started was 6.18 and decrease to 5.83. The subject was also not as interesting as they had expected it to be, as scores dropped from 6.15 to 5.89. The score on "Effort" also reduced from 6.68 to 6.05 .

Table 6

Comparison of mean scores

\begin{tabular}{llllll}
\hline \multirow{2}{*}{ Attitude Components } & Pre-test & & Post Test & P value \\
\cline { 2 - 6 } & Mean & Assessment & Mean & Assessment & \\
\hline Affect & 5.17 & Positive & 4.95 & Positive & 0.214 \\
\hline Cog. Comp & 5.48 & Positive & 5.28 & Positive & 0.161 \\
\hline Value & 6.18 & Positive & 5.83 & Positive & $0.002^{* *}$ \\
\hline Difficulty & 3.43 & Negative & 3.48 & Negative & 0.675 \\
\hline Interest & 6.15 & Positive & 5.89 & Positive & $0.043^{*}$ \\
\hline Effort & 6.68 & Positive & 6.05 & Positive & $0.000^{* *}$ \\
\hline Grand Mean & 5.51 & Positive & 5.25 & Positive & \\
\hline
\end{tabular}

* significant at $5 \%$

**significant at $1 \%$

\section{To Adapt the Sats-36 Model To A Sample Of Indian Business School Students}

An exploratory factor analysis with oblique rotation using 4 factors as opposed to the 6 factors in the original scale was administered only on the data collected before the semester begun. The technique was not employed on the second set of data as the size of the sample was small. Data was analysed using the R programming software.The scree diagram showed that the data could be analysed by using 4 factors as opposed to the six factors which were given by Schau. Parallel analysis also suggested that the number of factors is four. In keeping with earlier research a cut-off of 0.4 for the factor loadings was used (Comrey\&Lee,1992; Samuels,2017; Hatcher,1994; Vanhoof et.al 2011). The SS loadings for each factor was greater than 1 which showed that each factor was worth keeping. There were 3 items which had a loading of less than 0.4 and were not included 
in any attributes. These three statements are "I plan to study hard for every statistics test (Effort)", "I use statistics in my everyday life (Value)" and "Statistics is a subject quickly learned by most people (Difficulty)". The new components for the four factors are Affect, Interest, Value and Difficulty and their components are defined in table 7

Table 7

Attributes for the four factor model

\begin{tabular}{|c|c|}
\hline Attribute 1 - Affect & Loadings \\
\hline I will like statistics. & 0.6 \\
\hline I will feel insecure when I have to do statistics problems & 0.711 \\
\hline I will have trouble understanding statistics because of how I think & $0.538^{*}$ \\
\hline Statistics formulas are easy to understand & $0.474 * *$ \\
\hline Statistics is a complicated subject. & $0.567 * *$ \\
\hline I will get frustrated going over statistics tests in class & 0.578 \\
\hline I will be under stress during statistics class. & 0.628 \\
\hline I will enjoy taking statistics courses. & 0.665 \\
\hline I will make a lot of math errors in statistics. & $0.481^{*}$ \\
\hline I am scared by statistics. & 0.645 \\
\hline I will find it difficult to understand statistical concepts & $0.568^{*}$ \\
\hline \multicolumn{2}{|l|}{ Attribute 2 - Interest } \\
\hline I plan to complete all of my statistics assignments. & $0.41 * * *$ \\
\hline I plan to work hard in my statistics course. & $0.437 * * *$ \\
\hline Statistics should be a required part of my professional training. & $0.715 * * * *$ \\
\hline Statistical skills will make me more employable & $0.67 * * * *$ \\
\hline I am interested in being able to communicate statistical information to others & 0.513 \\
\hline I am interested in using statistics. & 0.586 \\
\hline I am interested in understanding statistical information. & 0.601 \\
\hline I plan to attend every statistics class session. & $0.534 * * *$ \\
\hline I am interested in learning statistics. & 0.567 \\
\hline I can learn statistics & $0.414^{*}$ \\
\hline I will understand statistics equations & $0.46^{*}$ \\
\hline \multicolumn{2}{|l|}{ Attribute 3 - Value } \\
\hline Statistics is worthless. & 0.491 \\
\hline I will have no idea of what's going on in this statistics course & $0.489 *$ \\
\hline Statistics is not useful to the typical professional & 0.654 \\
\hline Statistical thinking is not applicable in my life outside my job. & 0.566 \\
\hline Statistics conclusions are rarely presented in everyday life & 0.429 \\
\hline I will have no application for statistics in my profession. & 0.604 \\
\hline Statistics is irrelevant in my life & 0.71 \\
\hline \multicolumn{2}{|l|}{ Attribute 4 - Difficulty } \\
\hline Learning statistics requires a great deal of discipline. & 0.41 \\
\hline Statistics involves massive computations & 0.615 \\
\hline Statistics is highly technical & 0.713 \\
\hline Most people have to learn a new way of thinking to do statistics & 0.602 \\
\hline
\end{tabular}

The Statements marked with a * were earlier in the component of "Cognitive Competenc e", those marked with a ** were under "Difficulty", those with a *** were identified as i tems belonging to "Effort" and those with 4 stars belonged to "Value".

The Cronbachs Alpha value for reliability was calculated and the results are shown in ta ble 8 . 
Table 8

Cronbachs alpha value

\begin{tabular}{lll}
\hline Cronbach Alpha value & Pre -6 factor & Pre -4 factor \\
\hline Overall & 0.92 & 0.92 \\
\hline "Affect" & 0.85 & 0.9 \\
\hline "Cognitive Competence" & 0.79 & \\
\hline "Value" & 0.84 & 0.84 \\
\hline "Difficulty" & 0.7 & 0.68 \\
\hline "Interest" & 0.78 & 0.87 \\
\hline "Effort" & 0.64 & \\
\hline
\end{tabular}

These values show that the data collected is reliable overall as well as for the individual components.. The data for goodness of fit is displayed in Table 9.

Table 9

Goodness of fit indices

\begin{tabular}{lll}
\hline & Schau's original model & Modified model \\
\hline RMSR & 0.04 & 0.05 \\
\hline RMSEA & 0.052 & 0.065 \\
\hline Tucker Lewis Index of factoring Reliability & 0.871 & 0.846 \\
\hline
\end{tabular}

A value of between 0.05 and 0.08 for RMSR and RMSEA, which both models have, sho ws that they are acceptable. Values for Tucker Lewis Index at 0.871 and 0.846 also indi cate a good model fit. The Schau's 6 factor model is marginally better than the new mo del on all parameters. The cumulative Variance explained by the original model is $48 \%$ and for the four factor model is only $43 \%$. This also leads us to understand that the trad itional model is better than the new one.

\section{CONCLUSION}

The first objective of the paper is to investigate student's perceptions of the field of statistics using the SATS 36 scale. Based on the results, we get an appreciation of management student's content knowledge as well as their notions of statistics. Out of the six components studied, the high scores on the components of Effort, Value and Interest in both the pre and post tests show that students perceive the subject to be of value and interest but believe that they will need to put in effort too. All the scores come down for the post test scores showing that there is a minor decline in all three components pointing to the understanding that they found it more relevant and more difficult before starting the course. This leads us to the conclusion that there should be more emphasis on linking the subject to applications in the field of business which can be through discussions on contemporary developments or case studies. The score on effort also declines in the post test analysis which shows that students perceived it to be more difficult than it was. There is some difference in the responses gender wise on the items with most belonging to the affect component, which shows that female students are apprehensive as compared to male students about the course. Also, students who have positive experiences with math in their early academic life expect to enjoy the course and feel more confident of doing well in it as they have scored higher on the twin components of "Affect" and "Cognitive Competence". 
Differences are present in the attributes of Affect, Cognitive Competence and Difficulty according to gender, specialisation choices and previous math experience. The results of this study match with those of earlier studies which say that there is a difference in attitudes according to gender, with males being more inclined towards the subject (Coetzee \& Merwe, 2010; Hommik \& Luik, 2017; Paechter et al., 2017; Paul \& Cunnington, 2017) and contrary to the findings of research studies where males were found to be more anxious than females (Mandap, 2016) or there being no difference at all(Hassad, 2018). The findings of this study are also consistent with earlier studies that have reported positive attitudes for the course from students with positive previous math experiences (Coetzee \& Merwe, 2010; Macher et al., 2012; Paechter et al., 2017; Zhao et al., 2013). This study also shows that in a business school, the same statistics course need not be taught to students planning to pursue different specialisations in the second year. Students opting for Finance or Operations in the second year and then in their work life might have more use for the subject rather than those who would like to pursue Human Resources or Marketing. It might be worthwhile to cater to different sensibilities by making courses for different groups of students rather than having a vanilla course for all. It might also be worthwhile to revamp the subject syllabus and to make it more appealing and more relevant to students. This research reveals that those students who do not have a positive experience with math in their earlier academic life are more apprehensive about the course. The concerned faculty could make an attempt to dispel such fears by taking a bridge class before the actual commencement of the semester. This could be in the form of synchronous or asynchronous mode.

The factor analysis was conducted with six factors and four factors as well. In keeping with the earlier studies (Emmioglu Sarikaya et al., 2018; Persson et al., 2019; Vanhoof et al., 2011) it was found that the original six factor model was better than the four factor one. However, even for the six factor model the analysis suggests that there should be some more items in the scale. The SATS-36 scale does not factor in student's experience of working with different software in statistics classes or working with big data. Previous researchers have pointed out that working on software like R or SPSS adds value (Lai \& Williams, 2017; Sharma \& Desai, 2017; Zhou, 2018) from a student's perspective. A more comprehensive understanding of Statistics education would be possible if these are also included in the scale. Microsoft Excel and R programming language were used for this study. The software R was easy to handle and the output was easy to interpret.

\section{LIMITATIONS}

Longitudinal studies are needed to have a more thorough understanding of students' per ceptions and attitudes towards the subject. A mitigating variable might be the effect of th e faculty administering the course. This could be woven into the narrative in subsequent studies

\section{REFERENCES}

Aslemand, A. (2018). Undergraduate Social Sciences Students' Attitudes Toward Statistics [University of Toronto]. 
https://tspace.library.utoronto.ca/bitstream/1807/82943/3/Aslemand_Asal_201803_PhD _thesis.pdf

Bond, M. E., Perkins, S. N., \& Ramirez, C. (2012). Students ' perceptions of statistics : an exploration of attitudes, conceptualizations, and content knowledge of statistics. Statistics Education Research Journal, 11(2), 6-25. https://www.stat.auckland.ac.nz/ iase/serj/SERJ11(2)_Bond.pdf

Coetzee, S., \& Merwe, P. van der. (2010). Industrial psychology students ' attitudes towards statistics, 36(1), 1-8. https://doi.org/10.4102/sajip.v36i1.843

Comrey, A. L., \& Lee, H. B. (2013). A first course in factor analysis. Psychology press.

Dauphinee, T. L., Schau, C., \& Stevens, J. J. (1997). Survey of attitudes toward statistics: Factor structure and factorial invariance for women and men. Structural Equation Modeling, 4(2), 129-141. https://doi.org/10.1080/10705519709540066

DeVaney, T. a. (2009). Impact of video tutorials in an online educational statistics course. Journal of Online Learning and Teaching, 5(4), 600-608. http://jolt.merlot.org/vol5no4/devaney_1209.htm

Emmioglu Sarikaya, E., Ok, A., Aydin, Y. C., Schau, C., \& Sarikaya, E. E. (2018). Turkish Version of the Survey of Attitudes toward Statistics: Factorial Structure Invariance by Gender. International Journal of Higher Education, 7(121), 1927-6044. https://doi.org/10.5430/ijhe.v7n2p121

Et.al, A. (2019). Are there statistical anxiety differences between male and female students? Are there statistical anxiety differences between male and female students? https://doi.org/10.1088/1742-6596/1157/4/042127

François, K., Brussel, V. U., Pernambuco, U. F. De, \& Brussel, V. U. (2020). Big-data literacy as a new vocation for statistical literacy. Statistics Education Research Journal, 19(1), 194-205. https://iaseweb.org/documents/SERJ/SERJ19(1)_Francois.pdf?1583007154

Fullerton, J. a. ., \& Umphrey, D. (2001a). An Analysis of Attitudes Toward Statistics : In Annual Meeting of the Association for Education in Journalism and Mass Communication.

Fullerton, J. a. ., \& Umphrey, D. (2001b). An Analysis of Attitudes Toward Statistics : Annual Meeting of the Association for Education in Journalism and Mass Communication, 356-366. https://files.eric.ed.gov/fulltext/ED456479.pdf

Griffith, J. D., Adams, L. T., Gu, L. L., Hart, C. L., \& Nichols-Whitehead, P. (2012). Students' Attitudes Toward Statistics Across The Disciplines: A Mixed-Methods Approach. Statistics Education Research Journal, 11(2), 45-56.

Hatcher, L. (1994) A Step-by-Step Approach to Using the SAS System for Factor Analysis and Structural Equation Modeling. SAS Institute, Inc., Cary.

Hassad, R. A. (2018). Numeracy Advancing Education in Quantitative Literacy An Exploration of the Perceived Usefulness of the Introductory Statistics Course and 
Students' Intentions to Further Engage in Statistics An Exploration of the Perceived Usefulness of the Introductory Statistics Course and Students' Intentions to Further Engage in Statistics. 11(1). https://doi.org/10.5038/1936-4660.11.1.7

Hommik, C., \& Luik, P. (2017). Adapting the survey of attitudes towards statistics (Sats-36) for estonian secondary school students. Statistics Education Research Journal, 16(1), 228-239. https://iase-web.org/documents/SERJ/SERJ16(1)_Hommik.pdf

Howley, P., Bilgin, A. A., \& Prieto, E. (2017). Engaging students and teachers through statistics towards greater connection and social responsibility. Teaching Statistics in a Data Rich World Proceedings of the Satellite conference of the International Association for Statistical Education (IASE), July 2017, Rabat, Morocco

Katyal, N. (2020). Data Analytics Powers the Fight against Coronavirus. DQ India Online. https://www.dqindia.com/data-analytics-powers-fight-coronavirus/

Khavenson, T., Orel, E., \& Tryakshina, M. (2012). Adaptation of Survey of Attitudes Towards Statistics (SATS 36) for Russian Sample. Procedia - Social and Behavioral Sciences. https://doi.org/10.1016/j.sbspro.2012.05.440

Lai, G., \& Williams, D. (2017). Exploring Undergraduate Business Students ' Difficulties in Learning Statistics. 1954-1959.

Macher, D., Paechter, M., Papousek, I., \& Ruggeri, K. (2012). Statistics anxiety, trait anxiety, learning behavior, and academic performance. Source: European Journal of Psychology of Education Eur J Psychol Educ, 27(27). https://doi.org/10.1

Mandap, C. M. (2016). Examining gender differences in statistics anxiety among college students. 4(6), 357-366. https://www.ijern.com/journal/2016/June-2016/31.pdf

Martin, N., Hughes, J., \& Fugelsang, J. (n.d.). The roles of experience, gender, and individual differences in statistical reasoning 1. Retrieved December 19, 2017, from http://iase-web.org/documents/SERJ/SERJ16(2)_Martin.pdf

Melad, A. F. (2016). Comparative Study on Attitude towards Statistics for Business Undergraduates. Print) Sch. J. Phys. Math. Stat, 3(3), 110-116. https://doi.org/10.21276/sjpms.2016.3.3.3

Mónica, G., Silvia, P., \& Martín, G. (2016). 13th International Congress on Mathematical Education Hamburg , 24-31 July 2016 Teaching Probability and Statistics With E-Status. July, 2013-2016.

Paechter, M., Macher, D., Martskvishvili, K., \& Wimmer, S. (2017). Mathematics Anxiety and Statistics Anxiety. Shared but Also Unshared Components and Antagonistic Contributions to Performance in Statistics. 8(July), 1-13. https://doi.org/10.3389/fpsyg.2017.01196

Paul, W., \& Cunnington, R. C. (n.d.). An exploration of student attitudes and satisfaction in a gaise - influenced introductory statistics course 1. Retrieved December 19, 2017, from https://www.researchgate.net/profile/Warren_Paul/publication/321596829_An_explorati 
on_of_student_attitudes_and_satisfaction_in_a_GAISE-

influenced_introductory_statistics_course/links/5a2849a04585155dd42774443/An-

exploration-of-student-attitudes-and-satisfaction-in-a-GAISE-influenced-introductorystatistics-course.pdf

Paul, W., \& Cunnington, R. C. (2017). An exploration of student attitudes and satisfaction in a gaise-influenced introductory statistics course 1. Statistics Education Research Journal, 16(2), 487-510. https://iaseweb.org/documents/SERJ/SERJ16(2)_Paul.pdf

Persson, I., Kraus, K., Hansson, L., \& Wallentin, F. Y. (2019). Confirming the structure of the Survey Of Attitudes toward Statistics (Sats-36) by Swedish students. Statistics Education Research Journal, 18(1), 83-93.

Roberts, D. M., \& Bilderback, E. W. (1980). Reliability and validity of a statistics attitude survey. Educational and Psychological Measurement, 40(1), 235-238. https://doi.org/10.1177/001316448004000138

Samuels, P. (2017). Advice on exploratory factor analysis.

Schau, C. (2003). 2003 Joint Statistical Meetings - Section on Statistical Education. 2003 Joint Statistical Meetings, 3673-3683. http://statlit.org/pdf/2003SchauASA.pdf

Sharma, A. M. (2018). Study to understand stakeholders perception of statistics education in business schools [JJTU]. http://hdl.handle.net/10603/245895

Sharma, A. M., \& Desai, S. S. (2017). Student engagement and statistics education : A review of literature and future directions. International Journal of Academic Research and Development, 2(6), 869-882. http://www.academicsjournal.com/archives/2017/vol2/issue6/2-6-315

Vaidya, A. (2020). Covid-19: Maharashtra's Kolhapur deploys data analysis-driven tool to track returnees. Hindustan Times, Pune. https://www.hindustantimes.com/cities/covid-19-kolhapur-deploys-data-analysis-driventool-to-track-returnees/story-JZTF7A8wAFO4i7Gd0teGgI.html

Vanhoof, S., Kuppens, S., Sotos, A. E. C., Verschaffel, L., \& Onghena, P. (2011). Measuring statistics attitudes: Structure of the survey of attitudes toward statistics (SATS-36). Statistics Education Research Journal, 10(1), 35-51.

Zhao, Y., Lei, J., Yan, B., Lai, C., Tan, H. S., Wicks, D. A., Craft, B. B., Mason, G. N., Gritter, K., Bolding, K., Wisneski, J. E., Ozogul, G., Bichelmeyer, B. A., Waddoups, G. L., Howell, S. L., Valente, T. W., Rogers, E. M., Ulrich, J., Karvonen, M., ... Akcaoglu, M. (2013). A review of student engagement literature. The Internet and Higher Education, 16(2), 105-118. https://doi.org/10.1080/01587919.2013.770430

Zhou, Y. (2018). Blended teaching for research methods and statistics courses. International Journal of Social Sciences, 3(3), 1275-1283. 